the Einstein Institute for Science, Health and the Courts to begin a national programme to educate a thousand state and federal judges in genetics and molecular biology in the next two years and to sponsor conferences in related areas.

Third, the issue of Wesbecker's legal insanity is inadequately explored in the book. Cornwell classifies the insanity defence as an "excuse" defence. He attributes its underpinnings, as well as that of several theories of mitigation, to the Durham decision which he characterizes as the rule that acquits individuals of criminal behaviour by reason of "irresistible impulse". Unfortunately, this characterization is blatantly incorrect. In fact, Durham specifically rejected both the M'Naghten good-evil test and the irresistible-impulse test by finding that a broader test is appropriate.

The Durham judgment said: "We find that as an exclusive criterion the rightwrong test is inadequate in that (a) it does not take sufficient account of psychic realities and scientific knowledge, and (b) it is based upon one symptom and so cannot validly be applied in all circumstances. We find that the 'irresistible impulse' test is also inadequate in that it gives no recogni-

ADVERTISEMENTS

Martin Dunitz Publishers

\author{
DIGHLIGHTS ED \\ Frontiers in Multiple Sclerosis \\ Abramsky \& Ovadia \\ November 1996 . \\ ISBN 1-85317-384-3 • $£ 65.00$
}

An Atlas of Malignant Haematology

Mufti, Flandrin, Schaefer, Sandberg

\& Kanfer

1996 • ISBN 1-85317-054-2 • £115.00

Cytokines and Molecular Therapy

Editors: Talpaz \& Herrmann

Quarterly journal as reviewed in Nature

Institutional: UK \& EC - £135.00;

USA \& Canada $\$ 225.00 ;$ ROW $£ 145.00$

Personal: UK \& ROW - $\$ 65.00$

USA: $\$ 99.00$

Martin Dunitz Publishers has extensive current and forthcoming

lists in the following areas:

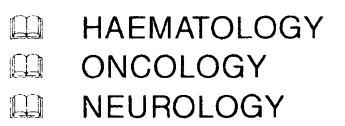

\section{$\overline{\text { MARTIN The Livery House }}$ DUNITZ 2 -9 Pratt Street DUNITZ Tel: 01714822202 PUBLISHING Fax: 01714827088}

Scientific publisher of

medical books and journals tion to mental illness to the application of the inadequate right-wrong test. We conclude that a broader test should be adopted."

Durham predicates the lack of criminal responsibility on a finding that the "unlawful act is the product of mental disease or defect". Durham came under rigorous criticism for being too heavily dependent on medical expertise and was overruled in 1972. US v. Brawner, which overruled Durham, added a volitional component to M'Naghten's cognitive inquiry. The Brawner test holds that defendants are not responsible for their criminal conduct if, as a result of mental disease or defect, they "lacked substantial capacity either to appreciate the criminality of their conduct or to conform their conduct to the requirements of law".

Kentucky law offers both a "not guilty by reason of insanity" (NGRI) verdict and a "guilty but mentally ill" (GBMI) verdict. About a third of the jurisdictions in the United States do likewise. Under GBMI, a person may be found guilty of the crime and mentally ill, but not legally insane at the time of the offence. People convicted under such a statute are sentenced to prison with the caveat that they are mentally ill and should receive treatment during their incarceration. The far more interesting question, not raised in the book, is whether Wesbecker would have been able successfully to use the insanity defence had he lived, and what impact, if any, an NGRI or GBMI verdict would have had on the subsequent civil proceedings.

Cornwell warns of the potential apocalypse created by "the growing crisis over reductionist solutions to individual suffering and social disorder". As society increasingly turns from social solutions to pharmacological quick-fixes, Cornwell foresees dire consequences. But he closes the book with hopeful musings on the enduring power of social solutions and leaves his readers to ponder the imperfect relationships between mind, medicine and murder.

Keri K. Gould is at the School of Law, Fordham University, 140 West 62nd Street, New York, New York 10023, USA.

\title{
When litigation becomes a lottery
}

\section{Lee Loevinger}

Science on Trial: The Clash of Medical Science and the Law in the Breast Implant Case. By Marcia Angell. Norton: 1996. Pp. 256. \$27.50, £22. Published in the United Kingdom in January 1997.

MARCIA Angell, executive editor of the New England Journal of Medicine, considers herself a feminist and a liberal Democrat but, above all, a scientist. She had no particular interest in silicone breast implants until the journal published two articles on the subject that indicated a discrepancy between the law and the scientific evidence.

By 1992, implants had been on the market for 30 years, between 1 million and 2 million women had them, and more than 90 per cent were pleased with them. But in April that year, David Kessler, commissioner of the US Food and Drug Administration (FDA), announced a virtual ban. At that time there was no scientific evidence that implants caused disease, but women panicked, and lawyers filed more than 30,000 suits against implant manufacturers.

In April 1994 a proposed settlement was approved in a class action that provided US $\$ 4.25$ billion to settle all claims. That sum included $\$ 1$ billion for lawyers' fees. The settlement provided for payment unconditionally to any woman who had received an implant without any signs of illness or other conditions caused by it. Advertisements inviting women to file claims appeared throughout the United States in newspapers and on television and radio.

In June 1994 the journal published the first epidemiological study of breast implants, and it found no association with disease. But by May 1995 more than 400,000 women had filed claims, Dow Corning, the principal defendant, was overwhelmed by the number of lawsuits and filed for bankruptcy, and the proposed settlement fell apart. Angell was struck by the discrepancy between the legal proceedings and the scientific evidence, and decided to write this book.

Although hooked on the apparent conflict between science and law, Angell is no zealot. She defends the function of the FDA while questioning, rather than condemning, the implant ban. She reports epidemiological studies done after 1994, and lucidly explains the relevance of the statistics, which continue to show no apparent connection between implants and disease.

What she "was not prepared to find was the extent of the financial involvement" of plaintiffs' lawyers, the complicity of some physicians, and cases resulting in relatively small gains for many women but enormous gains for a few lawyers.

The breast implant story also illustrates how subpoenas can be used to harass and intimidate scientists. The authors of breast implant studies have 
been served with excessive and burdensome document demands from plaintiffs' lawyers that would breach the confidentiality of medical records. These discourage, and may prevent, further scientific research, which will serve the interests of plaintiffs' lawyers but of no one else.

Other countries responded to unfolding evidence about breast implants quite differently from FDA. The United Kingdom imposed no ban, stating that there was no scientific evidence of increased risk of disease from breast implants. The practices causing the plague of lawsuits in the United States do not exist in the United Kingdom.

In such US cases, plaintiffs' lawyers have had contingency arrangements to receive fees of 30 to 40 per cent of all money recovered. Such arrangements are not permitted elsewhere. The large number of US claimants has been due to lawyers soliciting for clients through widespread advertising. British barristers are forbidden to advertise or to solicit clients. Finally, the exorbitant sums awarded in implant cases have been the product of jury sympathy rather than evidence, but only in the United States are such damages decided by juries.

Angell properly deprecates judicial ignorance of science, and is not hopeful that the 1993 US Supreme Court's opinion in the Daubert case, which established criteria for admissibility of scientific evidence, will be effective. The United States has 50 constitutionally sovereign state jurisdictions, each of which establishes its own evidentiary criteria, and which together handle a hundred times as many cases as the federal courts. Although most federal courts are at least beginning to require valid scientific evidence of causation, it will be years before all state courts adopt such standards, or other reforms.

Furthermore, class actions and unlimited punitive damages still provide ample opportunity for abuse; and a bill to limit such abuses was vetoed by President Bill Clinton last May.

Much has been written about implant cases, but mainly by journalists and lawyers. Angell presents a detailed, comprehensive, fairly balanced narrative from a scientific viewpoint. Yet the title is misleading - it is the law, rather than science, that is on trial in these cases. They teach that the alternative to science is not justice but ignorance; lacking scientific evidence of causation, litigation becomes a lottery.

Anyone concerned with the social impact of either science or law will find this book interesting and informative, as well as highly readable.

Lee Loevinger is at Hogan and Hartson, 555 Thirteenth Street NW, Washington DC 20004-1109, USA.

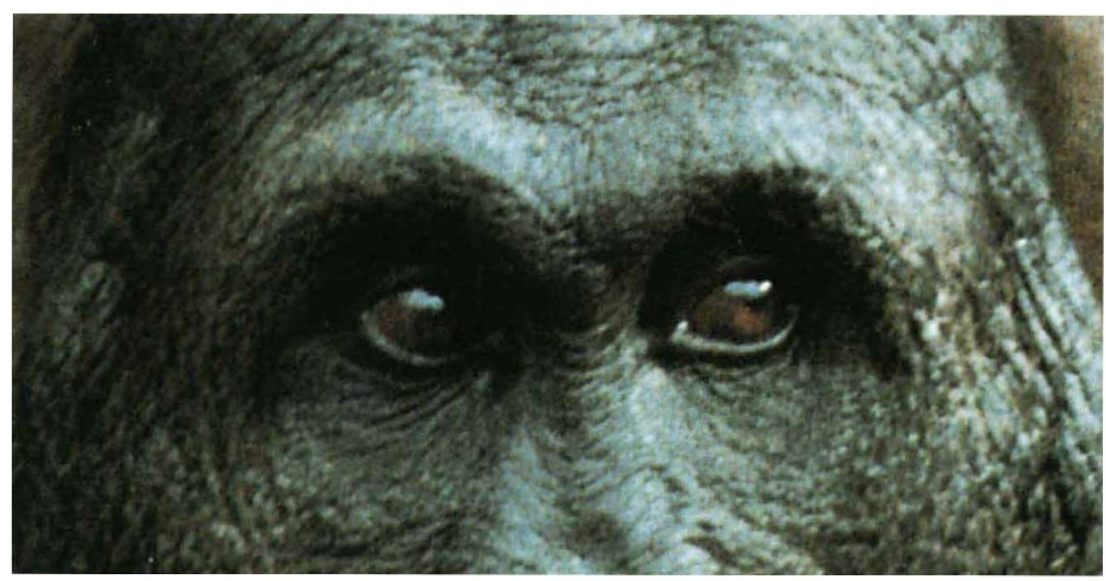

GrEAT apes can think at symbolic levels traditionally considered to be uniquely human. That is the claim of the field and laboratory researchers who contribute papers to Reaching into Thought: The Minds of the Great Apes, edited by Anne E. Russon, Kim A. Bard and Sue Taylor Parker Cambridge University Press, £55.

\section{Goodness denied}

\author{
Frans B. M. de Waal
}

The Origins of Virtue. By Matt Ridley. Viking: 1996. Pp. 295. £20. To be published in the United States in March 1997.

ANYONE who has watched the film $I l$ Postino realizes the extraordinary lure of the metaphor. The apprentice poet learns to offer a fresh, new look at the world through carefully selected analogies. Shy at first, he soon relishes the poet's proverbial 'licence' to transform reality.

Scientists lack such a licence. Metaphors are used in science to great effect and advantage, but also at great peril. When metaphors are taken literally, they begin to obscure the truth. This lot befell the wellknown struggle-for-existence view of the natural world. It kept generations of biologists from seeing the obvious conflux of interests among individuals and species even though Charles Darwin - always wiser than his followers - warned: "I use the term Struggle for Existence in a large and metaphorical sense including dependence of one being on another."

In The Origins of Virtue, Matt Ridley does an admirable job at documenting the mutual dependencies implied by Darwin, but not without getting seriously entangled in the field's latest metaphor according to which genes are selfish. Ridley, a British science writer who dazzled us, in 1993, with a well-received exposé of sexual evolution, The Red Queen, now reviews and elucidates the rich literature on tit-for-tat strategies, the prisoner's dilemma, group identity and other issues related to the evolution of altruism. The book is extremely well written, with the sort of anecdotal detail and wit that make for lively reading even when the most abstract topics are being treated. It should be of interest to anyone following the debates about the origins of cooperation and morality.

Although the influence of George Williams and William Hamilton is compared to that of Copernicus and Darwin surely a slight exaggeration - the book reads like a tribute to a third contemporary evolutionist: Robert Trivers. Trivers' ideas about reciprocal altruism are finally taking the central position in evolutionary accounts that they deserve; they are at the core of Ridley's argument about how 'virtue' might have come into existence. People enter into give-and-take deals, are concerned about their reputations within society and punish those who try to give less than they receive. We do unto others as we would have them do unto us; a rule that seems not too far removed from the way in which chimpanzees and some other animals selectively share food with those who share with them.

The author touches on a wide range of issues, from the growing interest of economists in commitments and fairness to the 'tragedy of the commons' - the overexploitation resulting when people share resources without restrictions - and the social policy implications of evolutionary theory. Leaning to the conservative side, as represented by Newt Gingrich and Margaret Thatcher, he argues that we are doomed if we keep denying our species' inherent opportunism and egoism. Society would work a whole lot better with less government and more room for private enterprise driven by human greed. Like Thatcher (according to whom "there is no such thing as society"), Ridley is not much of a believer in the greater good.

Although the chapter containing these ideas is prefaced by a self-mocking comment about how "the author suddenly and rashly draws political lessons", readers 